\title{
Reproductive traits and floral visitors of Aechmea distichantha plants growing in different habitats of a South American xerophytic forest
}

\author{
Rodrigo M. Freire ${ }^{1,2,3}$, Ignacio M. Barberis ${ }^{1,2}$ \& José L. Vesprini ${ }^{1,2}$
}

\begin{abstract}
Aechmea distichantha, a widely-distributed facultative epiphytic bromeliad species, is present from rainforests to xerophytic forests. At its southernmost distribution (Humid Chaco) it grows in the understory and forest edges. This animal-pollinated bromeliad shows high phenotypic plasticity on its vegetative traits, but there is no information about plasticity on its reproductive traits. Infructescences from shade plants were heavier, had longer rachis, more spikelets, higher number of fruits/spikelet and higher number of seeds/fruit than those from sun plants, but they presented similar number of open flowers. The number of visitation events was similar in both habitats, but more flowers were visited in the sun than in the shade. Flowers were visited by seven species (six insects and one hummingbird). In the sun, the carpenter bee was the most frequent visitor and visited almost all flowers, whereas in the shade different species of visitors attained similar proportion of visits and number of visited flowers. Despite visitation events were similar in both habitats, plants growing in the shade set more seeds/fruit than plants growing in the sun. The higher proportion of visits accomplished by carpenter bees compared to hummingbirds is probably a consequence of the climatic conditions in the austral location of these populations.
\end{abstract}

Key words: Aechmea distichantha, habitat, pollinators, reproductive characters.

\section{Resumen}

Aechmea distichantha es una bromeliácea epífita facultativa que se encuentra presente tanto en bosques lluviosos como en bosques xerofíticos. En el extremo sur de su distribución, el Chaco Húmedo, crece en el sotobosque y en los bordes del mismo. Esta bromeliácea polinizada por animales presenta alta plasticidad fenotípica en sus caracteres vegetativos, pero no existe información sobre su plasticidad en sus caracteres reproductivos. Encontramos que las infrutescencias de las plantas de sombra eran más pesadas, tenían mayor longitud de raquis, mayor número de espiguillas, de flores/espiguilla y de semillas/fruto que las de sol, pero presentaron similar número de flores abiertas en ambos hábitats. El número de visitas fue similar en ambos hábitats, pero más flores fueron visitadas al sol que a la sombra. Las flores fueron visitadas por siete especies (seis insectos y un colibrí). Al sol, el abejorro fue el visitante más frecuente y visitó casi todas las flores, mientras que a la sombra, la proporción de visitas y de flores visitadas estuvieron distribuidas más equitativamente entre las distintas especies. A pesar de que la cantidad de visitas fue similar en ambos hábitats, las plantas de sombra produjeron más semillas por fruto que las de sol. La mayor proporción de visitas de los abejorros en comparación con la de los colibríes es probablemente una consecuencia de las condiciones climáticas en la ubicación austral de estas poblaciones de $A$. distichantha.

Palabras-claves: Aechmea distichantha, hábitat, polinizadores, caracteres reproductivos.

\section{Introduction}

The Bromeliaceae is a large monocotyledon Neotropical family that has been traditionally divided into eight subfamilies: Brocchinioideae,
Lindmanioideae, Tillandsioideae, Hechtioideae, Navioideae, Pitcairnioideae, Puyoideae, and Bromelioideae (Givnish et al. 2011). Most bromeliad species are mainly pollinated by

\footnotetext{
${ }^{1}$ Universidad Nacional de Rosario, Facultad de Ciencias Agrarias, Cátedra de Ecología, Campo Experimental J.F. Villarino, S2125ZAA Zavalla, Santa Fe, Argentina.

${ }^{2}$ Instituto de Investigaciones en Ciencias Agrarias - CONICET, Campo experimental J.F. Villarino, S2125ZAA, Zavalla, Argentina.

${ }^{3}$ Author for correspondence: rodrigomanuelfreire@hotmail.com
} 
animals, but there are large differences in the relative importance of different pollinators (i.e., hummingbirds, bats, bees, moths, and butterflies) among bromeliad species (Benzing 2000; Kessler \& Krömer 2000; Givnish et al. 2014) and even within a bromeliad species (Schmid et al. 2011; Rocca \& Sazima 2013).

The pollinator assemblages visiting bromeliads are conditioned by resource availability, such as pollen and nectar (Canela \& Sazima 2005), as well as by some morphological traits of flowers, such as corolla color and length (Sazima et al. 1996). According to the bee avoidance hypothesis, these insects are excluded from red flowers due to their blindness for these wavelengths (Bergamo et al. 2016). Likewise, only hummingbirds and those insects whose tongues are long enough to reach the nectary chamber will be able to visit bromeliad flowers with depth-probed floral tube (Taura \& Laroca 2001; Vossler et al. 2014). Therefore, hummingbirds are expected to be more important than bees for bromeliads with deep red or pink flowers. For some bromeliad species pollinated by different agents, it is known that bees have lower effectiveness inducing seed set than hummingbirds (Schmid et al. 2011a). However, it is important to assess the contribution of different groups to the reproductive success by analyzing the seed set (Canela \& Sazima 2005).

Microclimatic factors are also known to influence pollination. Variability of irradiance associated with environmental heterogeneity has an effect on pollination by affecting foraging responses and thus on the composition of pollinator assemblages (Herrera 1995; Kilkenny Galloway 2008). Microclimatic factors such as irradiance may not influence the floral display, but may have a direct effect on pollinators behavior and consequently on plant reproductive success (Kilkenny \& Galloway 2008).

Aechmea distichantha Lem. (Bromeliodeae) is widely distributed in subtropical regions of South America from $14^{\circ}$ to $30^{\circ} \mathrm{S}$ (Smith \& Downs 1979). This facultative tank epiphyte lives in the canopy of the rain forests, as well as in the understory of seasonal dry and xerophytic forests from the sea level in the east to 2,200 $\mathrm{m}$ above the sea level in the west (Smith \& Downs 1979). It reproduces both sexually and asexually (Smith \& Downs 1979; Mercier \& Guerreiro Filho 1990; Bianchi et al. 2000; Scrok \& Varassin 2011). It flowers in the spring and in the summer, and no latitudinal or altitudinal patterns in flowering period have been described (Buzato et al. 2000; Marques et al. 2004; Scrok \& Varassin 2011; Vizentin-Bugoni et al. 2014; Vossler et al. 2014). Aechmea distichantha has hermaphrodite flowers, $12.4-18 \mathrm{~mm}$ in length (Sazima \& Sazima 1999; Krömer et al. 2006), arranged in an inflorescence composed of spikes of spikelets, with centripetal anthesis at the spike and at the spikelet levels. The anthesis extends for only one day (Sazima \& Sazima 1999; Scrok \& Varassin 2011) and the nectar produced in the septal nectaries accumulates at the bottom of the flower (Bernardello et al. 1991; Buzato et al. 2000; Scrok \& Varassin 2011; Oliveira et al. 2016). Flowers are pollinated by hummingbirds, perching birds, bees, and butterflies (Araujo 1996; Sazima et al. 1996; Sazima \& Sazima 1999; Taura \& Laroca 2001; Krömer et al. 2006; Scrok \& Varassin 2011; Bueno 2012; Rosa \& Monteiro 2012; Chupil 2013; Vizentin-Bugoni et al. 2014; Vossler et al. 2014), and has been described as partially self-compatible (Scrok \& Varassin 2011) or self-incompatible (Bianchi et al. 2000), but a few (5\%) fruit set was produced following self-pollination.

Plants of Aechmea distichantha exhibit high phenotypic plasticity; individuals growing in the sun are shorter, have shorter diameter, more leaves, and higher sheath biomass fraction than plants growing in the shade (Cavallero et al. 2009, 2011). The proportion of adult plants in reproductive stage is higher for plants growing in the shade (Barberis, Klekailo \& Galetti, unpublished data). Although phenotypic plasticity for vegetative characters has been demonstrated for this species, it is not known how reproductive characters are affected by environmental factors and if these variations in reproductive characters are associated with the composition of the pollinator assemblage.

Therefore, this work has two objectives. Firstly, to evaluate whether there are differences in the characteristics of the inflorescences (length and dry weight of floral rachis, spikelets per rachis, flowers per spikelets) between plants growing in the sun $v s$. those growing in the shade. As shade plants have larger biomass, it is expected a higher number of flowers in shade $v s$. sun plants. Secondly, to evaluate whether the activity of pollinators, the pollinator assemblage, and consequently the reproductive success (number of seeds per fruit), are affected by habitat differences and variations in inflorescence traits at different environments. As shade plants have larger inflorescences, a higher number of visits and an increase in the reproductive success are expected. 


\section{Material and Methods}

\section{Study area}

The study was carried out in a stand of Schinopsis balansae forest ('quebrachal'; Lewis et al. 1997), located at "Las Gamas", Santa Fe, Argentina (Estación Experimental Tito Livio Coppa, $29^{\circ} 28^{\prime} \mathrm{S}, 60^{\circ} 28^{\prime} \mathrm{W}, 58 \mathrm{~m}$ above the sea level). This site at the Cuña Boscosa Santafesina is located at the southernmost range of the distribution of $A$. distichantha of the Eastern Chaco (Lewis 1991; Barberis et al. 1998, 2002, 2014). The climate is humid temperate to warm, with a mean annual temperature of about $20^{\circ} \mathrm{C}$, and a mean annual precipitation of about $1,000 \mathrm{~mm}$. Rainfall is concentrated in the summer (December-March), and a dry season of variable length occurs during the winter (June-August) (Lewis \& Pire 1981). The forest is located on a mosaic of soils with low hydraulic conductivity, high sodium content and high electrical conductivity (Espino et al. 1983). These forests show high environmental heterogeneity, mostly related to topographic variation, with high density of woody species on relatively elevated patches, and open areas with grassy vegetation (Barberis et al. 2002). Aechmea distichantha plants are largely restricted to relatively elevated patches representing an important element of the understory, but may also grow at the edges of the open areas showing a gradient related to light exposure (Barberis et al. 2014). The populations are patchily distributed due to their clonal growth.

In the study area, it mainly flowers in the spring (September-November), even though it is not unusual to find flowering individuals throughout the year, even during the winter (J.L. Vesprini, personal observation).

Inflorescence traits and seed production

Fieldwork was conducted in December 2013. For 10 plants from the sun and 14 plants from the shade, we took one flower and measured the length of their corollas. We chose 30 plants growing in the shade of the understory and 12 plants exposed to full radiation. During fruit development, the infructescences keep all old flowers attached, including the ones that did not develop into fruits. Therefore we used the infructescences to determine the inflorescence traits. The infructescences were harvested, placed in paper bags, labelled and kept in a dark and dry place for two days until its processing. Then, each infructescence was oven-dried at $60{ }^{\circ} \mathrm{C}$ for 120 hours and weighed. We also measured the length of its rachis, and counted the number of spikelets. We randomly chose two spikelets from three different positions along the infructescence (bottom, middle, and top), and counted the number of fruits (six spikelets for each infructescence). Then we chose a fruit from the center of each spikelet and counted the number of seeds.

\section{Pollinator sampling}

In October 2013, we selected two forest patches separated by $20 \mathrm{~m}$ with about 14 flowering plants each. One patch was located in the sun and the other in the shade. We randomly selected six plants at each habitat, and for each inflorescence we counted the number of open flowers. During six days (22-27 October 2013) we carried out eight 10min sampling periods per day; two sampling periods in the morning (10:00-11:30 $\mathrm{h}$ ) and two others in the afternoon (16:30-18:00 h) for each habitat. In total, there were 44 sampling periods ( 22 in the sun and 22 in the shade). At each sampling period we recorded the identity of flower visitors, counted the number of visits and the number of flowers visited at each visit. One morning (26th October 2013), sampling was not carried out due to rainfall.

\section{Data analyses}

We applied the Student t-test to analyze differences in infructescence biomass, rachis length and number of spikelets between sun and shade plants. We applied the Bonferroni test to correct for multiple comparisons from a single data set, thus for these tests the significance P-value was set to $0.05 / 3=0.0167$. For other data set, we also used the Student t-test to analyze differences in corolla length between sun and shade plants. All these t-tests were carried out with the Rcmdr package in $R$ (Fox \& Bouchet-Valat 2016). We performed general linear mixed models with Poisson distribution to analyze differences in fruit number/spikelet and seed number/fruits between spikelets located at different positions, between sun and shade plants, as well as their interactions. Therefore, in these models, the habitat (sun vs. shade) and the spikelet position (bottom, middle, or top) were considered fixed factors, while the random factors considered the following nested structure. Fruits nested within spikelets, and spikelets nested within infructescence. We fitted a model with all terms (i.e., both fixed effects and their interaction) and a model without the interaction. Then we used maximum likelihood tests of nested models (i.e., with and without interactions) to evaluate the effect of the interaction (Crawley 2013). We used 
the function glmer from the lme4 package (Bates et al. 2015).

We used Kruskal-Wallis test to evaluate whether there were differences between habitats in the number of open flowers. We also applied this test to analyze if there were differences between habitats in the number of visits/10 $\mathrm{min}$ and the number of flowers visited/10 $\mathrm{min}$. These tests were used to analyze if there were differences between habitats in the number of visits/10 $\mathrm{min}$ and the number of flowers visited/10 min considering each visitor species separately and for all visitor species together. We used these non-parametric tests because the data sets were small and non-normally distributed. All analyses were carried out with the Rcmdr package in R (Fox \& Bouchet-Valat 2016).

We performed a multivariate analysis of variance to evaluate whether there were differences between habitats in the species composition of the assemblage of flower visitors. We used two matrices, one including number of visits/10 min and the other for number of flowers visited/10 $\mathrm{min}$. The sampling periods were used as replicates. This could inflate our sampling due repeated observations on the same plant individuals, but the differences between habitats seems to be consistent (see Results section). These multivariate analyses were carried out with the program MRPP (Multi-Response Permutation Procedure) of the PC-Ord package (McCune \& Mefford 2011) using the Sörensen index as a distance measure.

\section{Results}

Flowers from plants growing in both habitats presented similar corolla length (Sun: mean $=14.28$ $\mathrm{mm}, \mathrm{SD}=1.32$, Shade: mean $=15.23 \mathrm{~mm}, \mathrm{SD}=$ $0.95 ; \mathrm{t}=-2.05, \mathrm{P}=0.053)$. There were significant differences in infructescence traits between sun and shade plants (all $\mathrm{P}<0.05)$. The infructescences from plants growing in the shade were heavier $(\mathrm{t}=$ 3.06; $\mathrm{P}=0.0054)$, had longer rachis $(\mathrm{t}=3.93 ; \mathrm{P}=$ $0.0003)$, but had similar spikelets than those from sun plants ( $\mathrm{t}=-1.98 ; \mathrm{P}=0.0606)$ (Fig. 1). However, they presented similar number of open flowers in both habitats (Sun: Median $=3.5$, Range $=0-14$, Shade: Median $=6$, Range $=0-9 ; \mathrm{H}=0.106, \mathrm{P}=$ 0.745).

Shade plants had higher number of fruits/ spikelet and higher number of seeds/fruit $(\mathrm{P}<$ 0.05) (Fig. 2). In both habitats, spikelets located at the bottom had more fruits than spikelets located at its top $(\mathrm{P}<0.05)$ (Fig. 2). In contrast, there were no differences in number of seeds/fruits for spikelets located at different positions along the infructescences $(\mathrm{P}>0.05)$ (Fig. 2). Interactions were not significant (all P-values $>0.05$ ).

Visits happened in 25 out of the 4410 -min sampling periods ( 14 in the sun and 11 in the shade). We recorded 101 visitation events (53 in the sun and 48 in the shade) that resulted in 285 flowers visited (167 in the sun and 118 in the shade). Flowers were visited by six species of insects (four Hymenoptera, one Diptera, one Lepidoptera) and one hummingbird species (Chlorostilbon lucidus). In both habitats, most species were recorded only in $20 \%$ of the sampled periods (Fig. 3). The exception was the carpenter bee (Xylocopa ordinaria) which was recorded in half of the sampled periods in the sun (Fig. 3). The average visitation rate was 4.53 visits/flower/hour $(\mathrm{SE}=1.36)$ in the sun and 2.57 visits/flower/hour $(\mathrm{SE}=0.98)$ in the shade.

There were no differences between habitats in the number of inflorescences or flowers visited by all floral visitors (Fig. 5; Tab. 1). However, there were differences in the frequency of visit of different species between habitats. The carpenter bees carried out more visits to sun plants than to shade plants, whereas the unidentified Hymenoptera
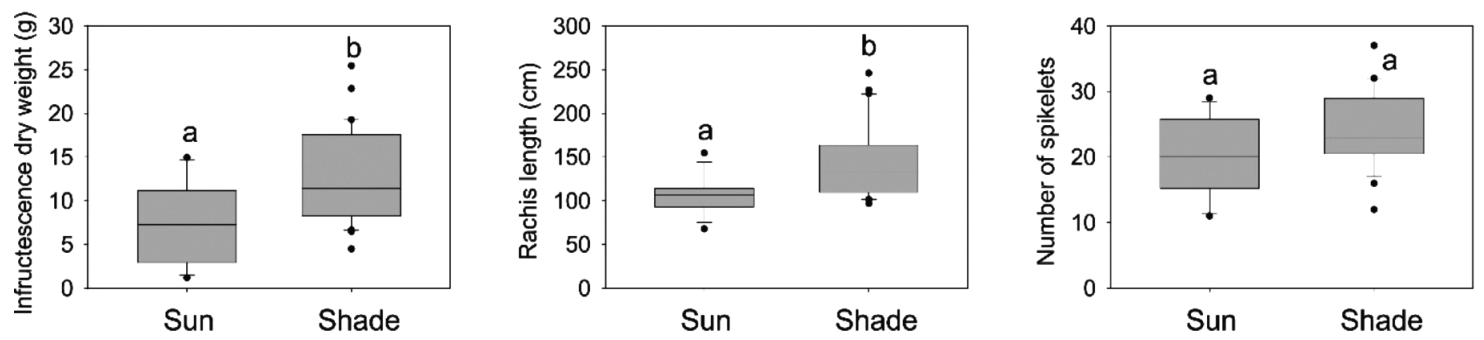

Figure 1 - Boxplots of infructescence dry weight, rachis length and number of spikelets of Aechmea distichantha plants grown in the sun and in the shade. Each boxplot includes the $25^{\text {th }}$ percentile, the median, and the $75^{\text {th }}$ percentile. Whiskers (error bars) above and below the box indicate the 90 and $10^{\text {th }}$ percentiles. For each variable, values with the same letters are not significantly different. 
Sun
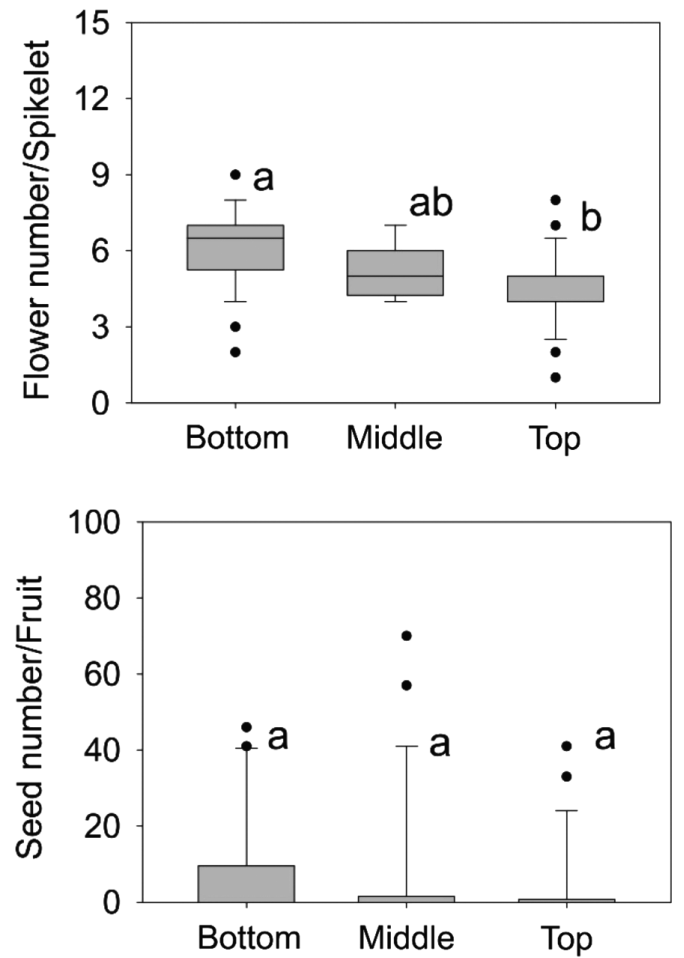

Shade
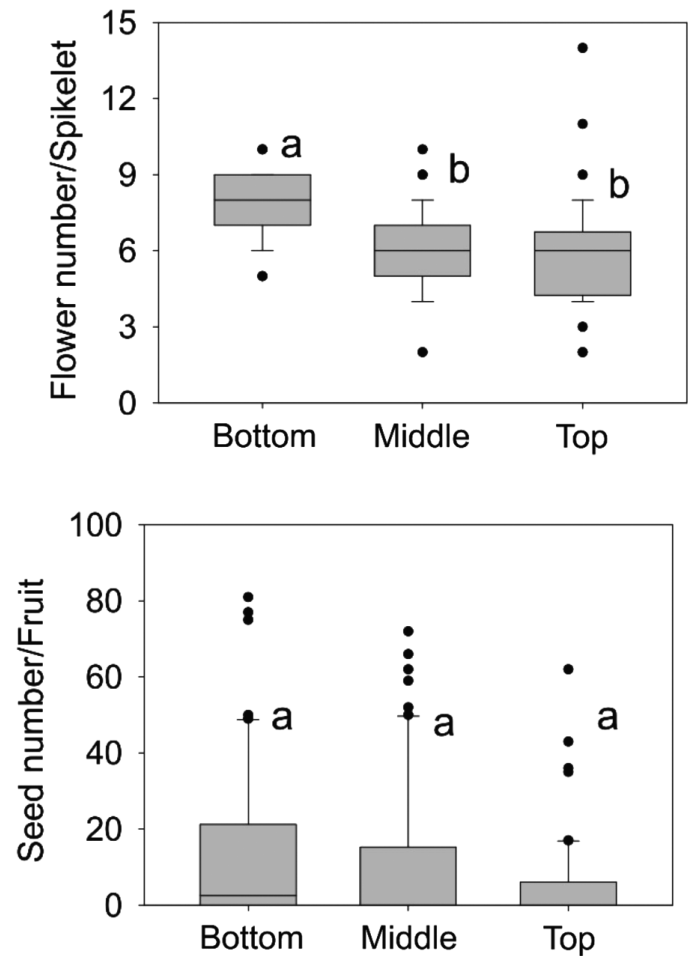

Figure 2 - Boxplots of flower number/spikelet and seed number/flower for spikelets located at the bottom, middle or top of the infructescence of Aechmea distichantha plants grown in the sun and in the shade. Each boxplot includes the $25^{\text {th }}$ percentile, the median, and the $75^{\text {th }}$ percentile. Whiskers (error bars) above and below the box indicate the 90 and $10^{\text {th }}$ percentiles. For each variable, values with the same letters are not significantly different.

species showed the opposite pattern (Fig. 5; Tab. 1). Even though three species were recorded only at one site (the unidentified Vespidae species and the hummingbird in the shade plants, and Polistes canadiensis in the sun) the number of observations was too low to detect significant differences between habitats (Tab. 1). The butterfly (Lepidoptera: Pieridae; one species) and the fly (Diptera: Syrphidae; one species) were recorded in both habitats, but there were no significant differences between habitats (Tab. 1). Many honey bees (Apis mellifera) were observed in the area

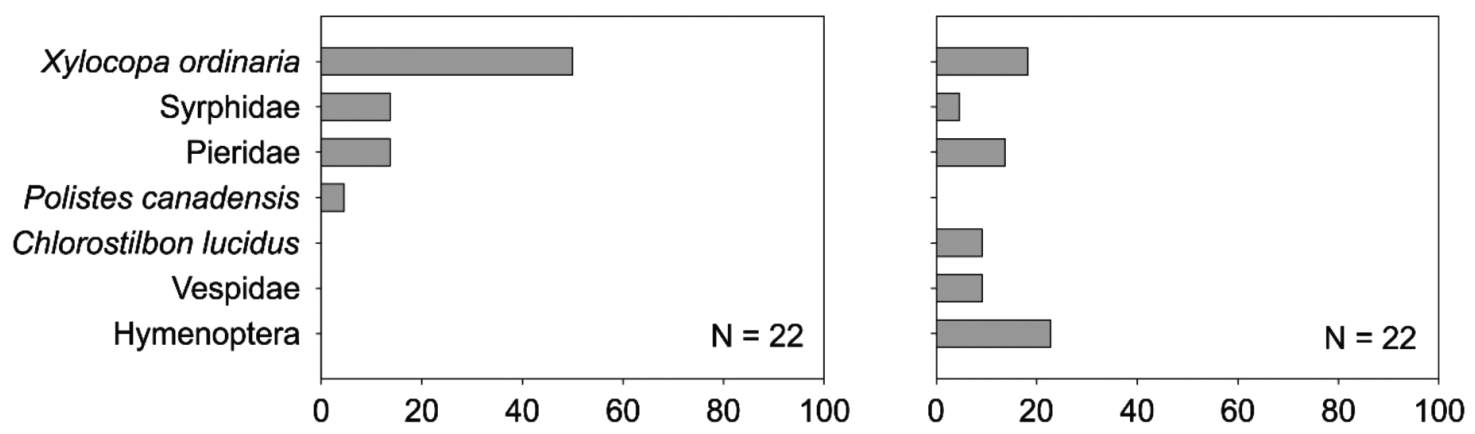

$\%$ of observation periods visited in the sun $\%$ of observation periods visited in the shade

Figure 3 - Percentage of the sampled periods at each habitat where each animal species was present visiting Aechmea distichantha inflorescences. $\mathrm{N}$ denotes the number of sampled periods visited at each habitat. 

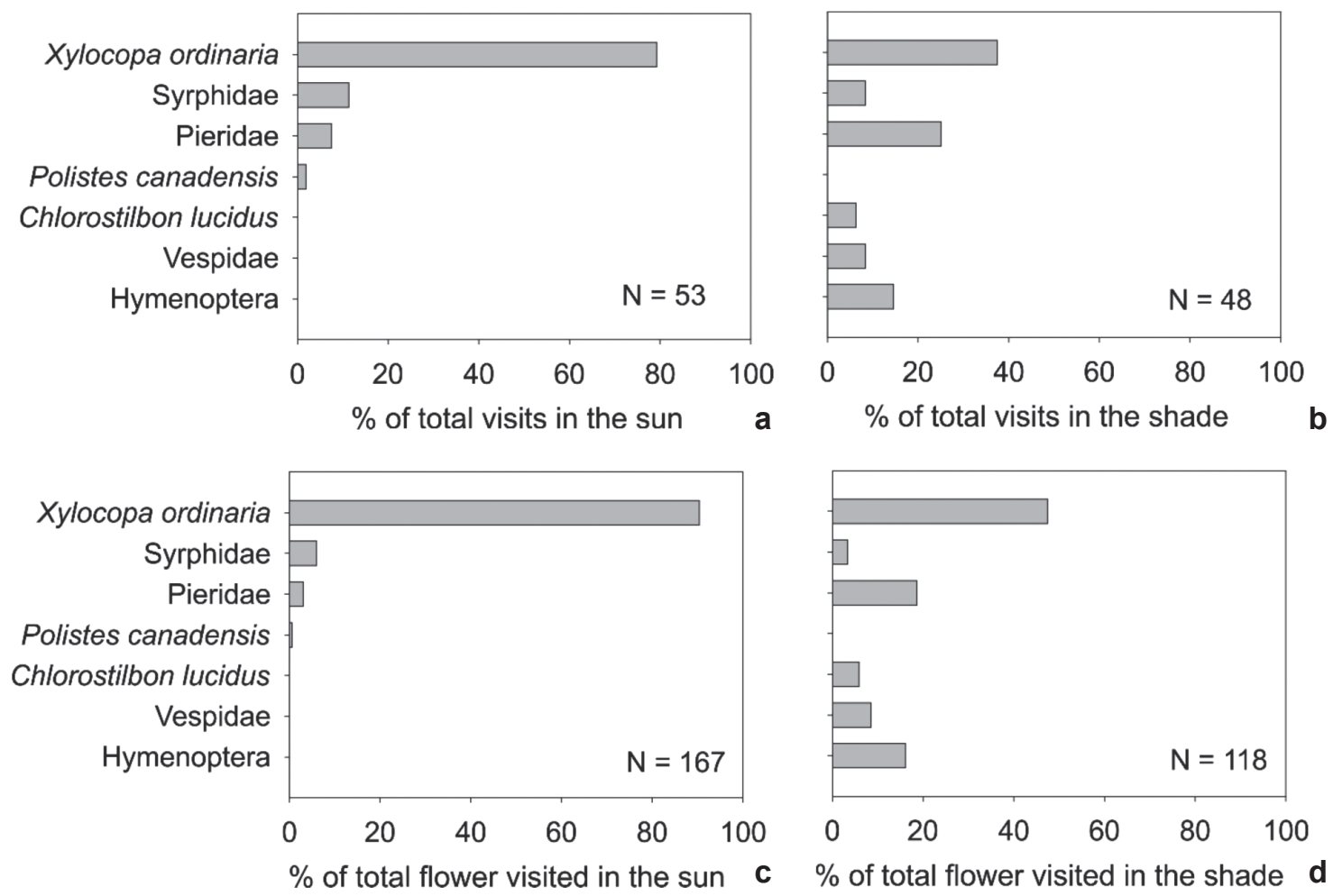

Figure 4 - Percentage distribution of Aechmea distichantha plants visited by different animal species in the sun (a) and in the shade (b), and percentage distribution of the number of flower visited by different animal species in the sun (c) and in the shade (d). $\mathrm{N}$ denotes the number of visits at each habitat (a and b) and the number of flowers visited (c and d).

drinking water in the phytotelmata, but no flower visits were recorded for this species.

There were significant differences between habitats in the community of floral visitors, either measured as number of visits/10 min (MRPP test, $\mathrm{A}=0.053, \mathrm{P}=0.016)$ or as number of flower visited/10 $\mathrm{min}$ (MRPP test, $\mathrm{A}=0.039, \mathrm{P}=0.035$ ). In the sun, the carpenter bee was the most frequent visitor and visited almost all flowers, whereas in the shade different species of visitors attained similar proportion of visits and number of visited flowers (Fig. 4) We acknowledge that our sampling may be inflated due repeated observations on the same individuals. However, the differences in assemblages seem to be strong despite this statistical limitation.

\section{Discussion}

\section{Plant traits}

Infrutescences from plants growing in the shade had longer rachis and higher number of fruits than those from sun plants. Nonetheless, inflorescences had similar number of open flowers per day in both habitats. A similar pattern was recorded in southern Brazil (Scrok \& Varassin 2011). This result indicates that bigger inflorescences do not offer a higher number of open flowers each day, and thus probably offer similar amount of nectar at both habitats. Additionally, it should be taken into account that bigger inflorescences can offer reward for longer periods (Firmage \& Cole 1988; Kilkenny \& Galloway 2008).

Aechmea distichantha displays a corolla of 18-20 mm length and the floral tube has a small diameter that allows medium and long-tongued bees to reach the nectar On the other hand, the flowers seem to hinder the access to short-tongued bees that have no access to nectary chambers because of the combination of the length of their proboscis and the floral tube morphology (length and width) such as A. mellifera. There are some reports for medium- or long-tongued bees (Taura \& Laroca 2001; Vossler et al. 2014) these reports are supported by our records of honey bees drinking water in the phytotelmata but not visiting the flowers. 
Pollinator assemblage

Previous studies on the reproductive biology of $A$. distichantha carried out in areas located at lower latitudes reported hummingbirds and butterflies as its main flower visitors (Bernardello et al. 1991; Araujo 1996; Buzato et al. 2000; Scrok \& Varassin 2011; Rosa \& Monteiro 2012; Chupil 2013; Vizentin-Bugoni et al. 2014). In contrast, in this study conducted at the southern distribution range of $A$. distichantha we found that carpenter bees are the main pollinators (in terms of visitation rates). Differences in the pollinator assemblages can be explained by different latitudes and climatic conditions (Krömer et al. 2006), but the plant community composition may also play a central role in the assemblage of pollinators due to changes in the floral neighborhood (Lázaro et al. 2009). In the studied community, ornithophilous species are
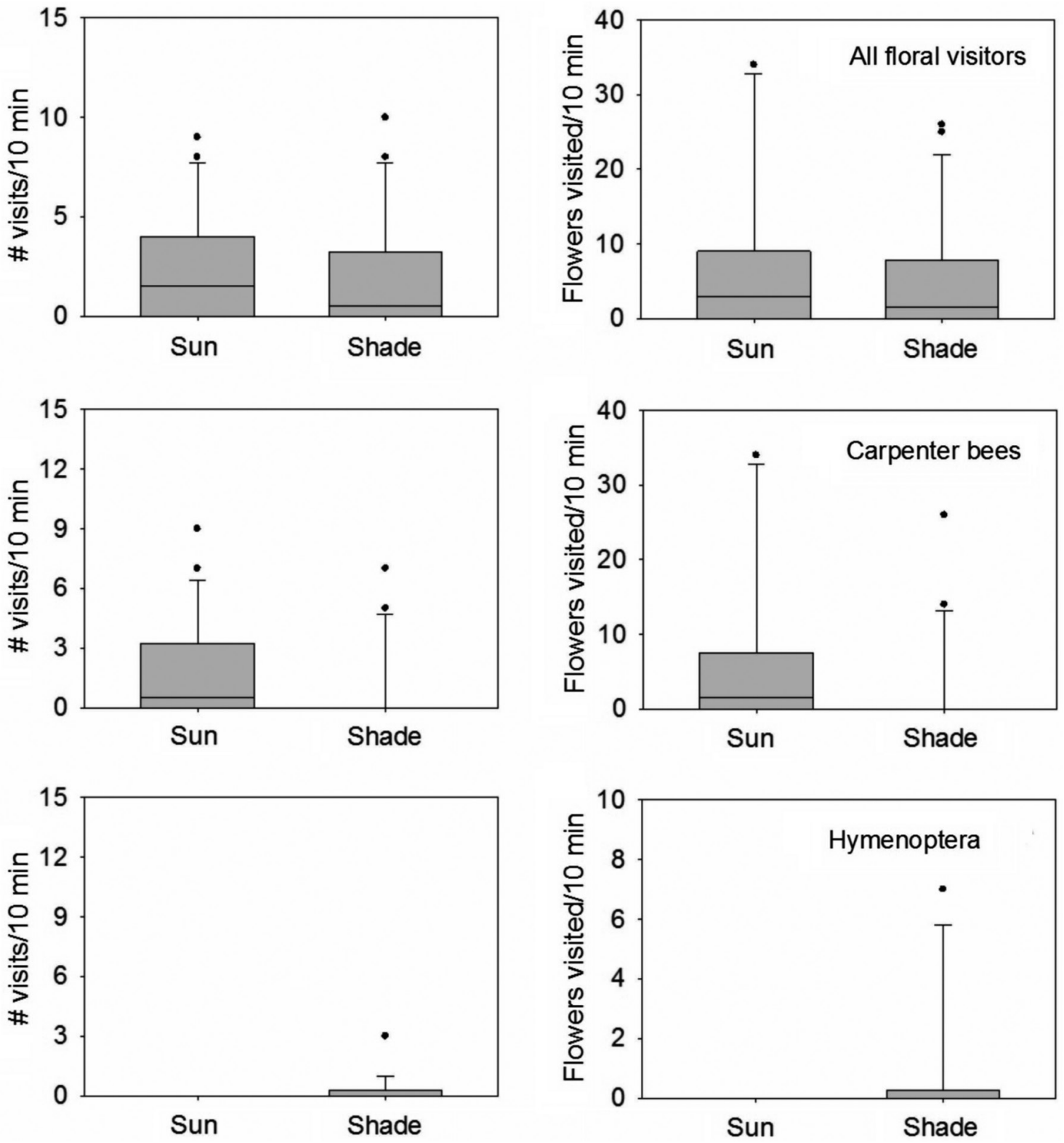

Figure 5 - Boxplots of Aechmea distichantha plants in the sun and in the shade visited by each animal species. Each boxplot includes the $25^{\text {th }}$ percentile, the median, and the $75^{\text {th }}$ percentile. Whiskers (error bars) above and below the box indicate the 90 and $10^{\text {th }}$ percentiles. 
Table 1 - Results of tests to evaluate differences in number of visits/10 min and number of flowers visited/10 min between sun and shade habitats for all floral visitors and for each visitor species.

\begin{tabular}{lccccc}
\hline & \multicolumn{2}{c}{ Visits/10 min } & & \multicolumn{2}{c}{ Flower visited/10 min } \\
\cline { 2 - 3 } \cline { 5 - 6 } & KW-Chi.squared & $\mathbf{P}$ & & KW-Chi.squared & $\mathbf{P}$ \\
\hline All floral visitors & 0.361 & 0.5478 & & 0.277 & 0.5985 \\
Xylocopa ordinaria & 3.952 & $\mathbf{0 . 0 4 6 8}$ & & 4.059 & $\mathbf{0 . 0 4 3 9}$ \\
Hymenoptera sp & 5.500 & $\mathbf{0 . 0 1 9 0}$ & & 5.490 & $\mathbf{0 . 0 1 9 1}$ \\
Vespidae sp. & 2.047 & 0.1526 & & 2.047 & 0.1526 \\
Polistes canadiensis & 1.000 & 0.3173 & & 1.000 & 0.3173 \\
Syrphidae sp. & 0.931 & 0.3347 & & 1.072 & 0.3004 \\
Chlorostilbon lucidus & 2.047 & 0.1526 & & 2.047 & 0.1526 \\
Pieridae sp. & 0.031 & 0.8595 & & 0.031 & 0.8595 \\
\hline
\end{tabular}

Note: The Kruskal Wallis and P values are shown. Significant results are shown in bold.

scarce and only represented by a liana (Dolichandra cynanchoides), few epiphytes (Tillandsia spp.) and a cactus (Cleistocactus baumanii) (Bianchi et al. 2000; Vesprini, personal observation), which mainly flower during the spring and the summer. Although a few individuals of $A$. distichantha were observed flowering in winter, there would not be abundant winter floral resources for large populations of hummingbirds. In contrast, carpenter bees not only are able to forage on a larger number of plant species, but they also collect pollen, and have lower energy requirements (Heinrich 1975). Therefore, it is likely that the high proportion of visits accomplished by carpenter bees is a consequence of the austral location of these $A$. distichantha populations and also of the climatic conditions favoring a large number of bees.

Hymenoptera species have been considered functional pollinators for other bromeliad species (Abrahamovich et al. 2001; Fumero-Cabán \& Meléndez-Ackerman 2007; Kamke et al. 2011; Schmid et al. 2011a, 2011b, 2011c; Guerra et al. 2012). For instance, Xylocopa, Bombus and some species of Augochlorine bees induced seed set in Aechmea nudicaulis, albeit with much lower effectiveness than hummingbirds. However, the low effectiveness of bees may be compensated by their much higher frequency of flower visitation (Schmid et al. 2011a). Besides, the low effectiveness of bees may be coupled with low quality pollination with regard to a higher proportion of visits leading to selfing vs. outcrossing (Bergamo et al. 2016).
Pollinator assemblage and reproductive success in different habitats

The number of visitation events was similar in sun and shade habitats. However, our results suggest that pollinator assemblages are conditioned by habitat, with carpenter bees showing strong preferences for foraging in the sun. An effect of irradiance on the pollinator assemblage composition was also found in another study: endothermic pollinators (large-size bees) visited flowers independently of habitat while ectothermic insects (small-size bees and butterflies) discriminated between sun and shade patches (Herrera 1995). Interactions between pollinators may also be important in the studied case. In a study on Impatiens biflora pollinated by a hummingbird and two large bees, it was found that individuals of one pollinator species can be largely excluded from access to nectar by foragers of other pollinator species with larger tongues. It is likely that hummingbirds would not have problems to forage in sunny habitats, but nectar is depleted at sun a large frequency of visits attained by bees (Laverty \& Plowright 1985).

In our study, as carpenter bees have a high visitation rate, more flowers were visited in the sun than in the shade. Conversely there were 2.41 more seeds produced per infructescences in the shade than in the sun (i.e., 1,650 vs. 681 seeds/infructescence). In contrast, Scrok \& Varassin (2011) recorded more seeds in the sun 
than in the shade (about 19,500 vs. 8,000 seeds/ infructescence). This is probably an effect of quantity of visits, that is leading to a higher seed set in the sun. It should be taken into account that seed production at our site was an order of magnitude lower than in Brazil, mainly due to a lower seed number/fruit, as fruit number/infructescence is similar at both sites. Thus, assuming that the number of ovules/flower is similar at both sites, it is likely that seed production could be limited by pollination. In this sense, there is an effect of geographical distribution of plants populations on the number of pollinator species and the frequency of visits, which are commonly low in southern latitudes (Bernardello et al. 1994). Moreover, $A$. distichantha has been reported as partially selfcompatible in Brazil (Scrok \& Varassin 2011), but self-incompatible at our study site (Bianchi et al. 2000). It is possible that differences in seed set success could be related to differences in the breeding system of this species (Knight et al. 2005). In addition, pollen limitation has been shown for other bromeliad species (Paggi et al. 2007; Ramírez Morillo et al. 2009; Wolowski et al. 2014).

It seems to exist a contradiction between the higher average visitation rate found in the sun and the higher seed set in the shade (i.e., higher number of fruits/spikelet and higher number of seeds/fruits), considering that the amount of open flowers at a given time was the same at both habitats. On one hand, this could be related to the higher pollinator richness in the shade, because for other plant species it has been shown that seed set is more affected by the diversity than by the abundance of pollinators (Aizen 2007). It is important to consider that the quality of the visits of bees may be lower than the visits accomplished by hummingbirds, and that sunny habitats may have fewer nutrients which may affect seed set of sun plants. On the other hand, we did not record the length of the flowering period at both habitats. However, when we carried out the survey there was similar number of open flowers between habitats, but since shade plants have more flowers per inflorescence it is possibly that they remain with open flowers for longer periods.

At our study site it is rare to observe seedlings originated from seeds. Thus, even though sexual reproduction could be very important for habitat colonization, it is not easy to determine whether these differences found in the ability to produce seeds between plants located at different habitats have an adaptive value. For species, whose reproduction within a colonized habitat is secured by clonality, the importance of sexuality (asexual $v s$. sexual) would be higher in other processes like clone rejuvenilization or maintenance of genetic variability (Silvertown \& Lovett Doust 1993).

\section{Final comments}

Habitat influences most inflorescence traits, with shade plants having bigger inflorescences than those in the sun. However, a similar number of flowers per plant are open each day in both habitats, and thus a higher nectar reward for pollinators is not expected between habitats.

At the southernmost portion of its distribution range, this bromeliad species is mainly visited by insects. The pollinator assemblage composition and the visitation rate vary between habitats. The existence of pollinator assemblages between habitats was unexpected. In the sun, the carpenter bee was the most frequent visitor and visited almost all flowers, whereas in the shade different species of visitors attained similar proportion of visits and number of visited flowers.

A higher pollinator richness in the shade may be associated with a higher reproductive success, evidenced by a higher seed set. The observed variation in seed production between habitats has not necessarily an adaptive value because sexual reproduction of this species does not play an important role in the structure and dynamic of its populations.

Finally, factorial experiments would be the most suitable step to test most of the hypotheses here presented, since it would allow to control many environmental variables, as well as biotic interactions.

\section{Acknowledgements}

We thank Ministerio de la Producción, Provincia de Santa Fe for allowing access to Las Gamas field station. We thank G. Klekailo, V. Albute and E. Kirilovsky for their help during field work, and J. Asmus and A. Tessore for helping to process the inflorescences. We thank G. Montero for valuable comments on the manuscript. This work was supported by the Agencia Nacional de Promoción Científica y Tecnológica under Grant [PICT2010-1614]. JLV \& IMB are members of Consejo Nacional de Investigaciones Científicas y Técnicas. We thank two reviewers and the editor for their valuable comments that greatly improved the manuscript. 


\section{References}

Abrahamovich AH, Tellería MC \& Díaz NB (2001) Bombus species and their associated flora in Argentina. Bee World 82: 76-87.

Aizen MA (2007) Enfoques en el estudio de la reproducción sexual de las plantas en ambientes alterados: limitaciones y perspectivas. Ecología Austral 17: 7-19.

Araujo AC (1996) Beija-flores e seus recursos florais numa área de planicie costeira do litoral norte de São Paulo. Magister Scientiae Thesis. Universidade Estadual de Campinas, Campinas. 69p.

Barberis IM, Pire EF \& Lewis JP (1998) Spatial heterogeneity and woody species distribution in a Schinopsis balansae (Anacardiaceae) forest of the Southern Chaco, Argentina. Revista de Biología Tropical 46: 515-524.

Barberis IM, Batista WB, Pire EF, Lewis JP \& León RJC (2002) Woody population distribution and environmental heterogeneity in a Chaco forest, Argentina. Journal of Vegetation Science 13: 607614.

Barberis IM, Torres PS, Batista WB, Magra G, Galetti L \& Lewis JP (2014) Two bromeliad species with contrasting functional traits partition the understory space in a Southamerican xerophytic forest: Correlative evidence of environmental control and limited dispersal. Plant Ecology 215: 143-153.

Bates D, Maechler M, Bolker B \& Walker S (2015) Fitting Linear Mixed-Effects Models using lme4. Journal of Statistical Software 67: 1-48.

Benzing DH (2000) Bromeliaceae. Profile of an adaptive radiation. Cambridge University Press, Cambridge. $708 \mathrm{p}$.

Bergamo PJ, Rech AR, Brito VG \& Sazima M (2016) Flower colour and visitation rates of Costus arabicus support the 'bee avoidance' hypothesis for red-reflecting hummingbird-pollinated flowers." Functional Ecology 30: 710-720.

Bernardello LM, Galetto L \& Juliani HR (1991) Floral nectar, nectary structure and pollinators in some Argentinean Bromeliaceae. Annals of Botany 67: 401-411.

Bernardello L, Galetto L \& Rodriguez IG (1994) Reproductive biology, variability of nectar features and pollination of Combretum fruticosum (Combretaceae) in Argentina. Botanical Jouranl of the Linnean Society 114: 293-308.

Bianchi MB, Gibbs PE, Prado DE \& Vesprini JL (2000) Studies on the breeding systems of understorey species of a Chaco woodland in NE Argentina. Flora 195: 339-348.

Buzato S, Sazima M \& Sazima I (2000) Hummingbirdpollinated floras at three Atlantic forest sites. Biotropica 32: 824-841.

Canela M \& Sazima M(2005) The pollination of Bromelia antiacantha (Bromeliaceae) in Southeastern Brazil: ornithophilous versus melittophilous features. Plant Biology 7: 411-416.

Cavallero L, López D \& Barberis IM (2009) Morphological variation of Aechmea distichantha (Bromeliaceae) in a Chaco forest: habitat and sizerelated effects. Plant Biology 11: 379-391.

Cavallero L, Galetti L, López D, McCargo J \& Barberis IM (2011) Morphological variation of the leaves of Aechmea distichantha Lem. plants from contrasting habitats of a Chaco forest: a trade-off between leaf area and mechanical support. Revista Brasileira de Biociências 9: 455-464.

Chupil H (2013) Uso de grãos de pólen na identificação de plantas e para examinar a partição de nicho alimentar entre beija-flores no sul do Brasil. Magister Scientiae Thesis. Universidade Federal de Paraná, Curitiba. 84p.

Crawley MJ (2013) The R book. $2^{\text {nd }}$ ed. John Wiley \& Sons, West Sussex. 1060p.

Espino LM, Seveso MAN \& Sabatier MA (1983) Mapa de suelos de la provincia de Santa Fe. MAG Santa Fe and INTA EERA Santa Fe, Santa Fe. 249p.

Firmage DH \& Cole FR (1988) Reproductive success and inflorescence size of Calopogon tuberosus (Orchidaceae). American Journal of Botany 75: 1371-1377.

Fox J \& Bouchet-Valat M (2016) Remdr: R Commander. R package version 2.3-1. Available at $<$ http://www. r-project. org $>$. Access on 15 August 2016.

Fumero-Caban JJ \& Melendez-Ackerman EJ (2007) Relative pollination effectiveness of floral visitors of Pitcairnia angustifolia (Bromeliaceae). American Journal of Botany 94: 419-424.

Givnish TJ, Barfuss MHJ, Ee BV, Riina R, Schulte K, Horres R, Gonsiska PA, Jabaily RS, Crayn DM, Smith JAC, Winter K, Brown GK, Evans TM, Holst BK, Luther H, Till W, Zizka G, Berry PE \& Sytsma KJ (2011) Phylogeny, adaptive radiation, and historical biogeography in Bromeliaceae: insights from an eight-locus plastid phylogeny. American Journal of Botany 98: 872-895.

Givnish TJ, Barfuss MH, Ee BV, Riina R, Schulte K, Horres R, Gonsiska PA, Jabaily RS, Crayn DM \& Smith AC (2014) Adaptive radiation, correlated and contingent evolution, and net species diversification in Bromeliaceae. Molecular Phylogenetics and Evolution 71: 55-78.

Guerra T, Romero G, Costa J, Lofego A \& Benson W (2012) Phoretic dispersal on bumblebees by bromeliad flower mites (Mesostigmata, Melicharidae). Insectes Sociaux 59: 11-16.

Heinrich B (1975) Energetics of pollination. Annual Review of Ecology and Systematics 6: 139-170.

Herrera CM (1995) Microclimate and individual variation in pollinators: flowering plants are more than their flowers. Ecology 76: 1516-1524.

Kamke R, Schmid S, Zillikens A, Lopes BC \& Steiner $\mathrm{J}$ (2011) The importance of bees as pollinators in 
the short corolla bromeliad Aechmea caudata in southern Brazil. Flora 206: 749-756.

Kessler M \& Krömer T (2000) Patterns and ecological correlates of pollination modes among bromeliad communities of Andean forests in Bolivia. Plant Biology 2: 659-669.

Kilkenny FF \& Galloway LF (2008) Reproductive success in varying light environments: direct and indirect effects of light on plants and pollinators. Oecologia 155: 247-255.

Knight TM, Steets JA, Vamosi JC, Mazer SJ, Burd M, Campbell DR, Dudash MR, Johnston MO, Mitchell RJ \& Ashman TL (2005) Pollen limitation of plant reproduction: pattern and process. Annual Review of Ecology and Systematics 36: 467-497.

Krömer T, Kessler M \& Herzog SK (2006) Distribution and flowering ecology of bromeliads along two climatically contrasting elevational transects in the Bolivian Andes. Biotropica 38: 183-195.

Laverty TM \& Plowright R (1985) Competition between hummingbirds and bumble bees for nectar in flowers of Impatiens biflora. Oecologia 66: 25-32.

Lázaro A, Lundgren R \& Totland Ø (2009) Coflowering neighbors influence the diversity and identity of pollinator groups visiting plant species. Oikos 118: 691-702.

Lewis JP \& Pire EF (1981) La Vegetación de la República Argentina. Reseña sobre la vegetación del Chaco Santafesino. Serie Fitogeográfica: 18.

Lewis JP (1991) Three levels of floristical variation in the forests of Chaco. Journal of Vegetation Science 2: 125-130.

Lewis JP, Pire EF \& Barberis IM (1997) Structure, physiognomy and floristic composition of a Schinopsis balansae (Anacardiaceae) forest in the Southern Chaco, Argentina. Revista de Biología Tropical 45: 1013-1020c.

Marques MCM, Roper JJ \& Baggio Salvalaggio AP (2004) Phenological patterns among plant lifeforms in a subtropical forest in southern Brazil. Plant Ecology 173: 203-213.

McCune B \& Mefford MJ (2011) Multivariate analysis of ecological data. MjM Software, Gleneden Beach. Available at <http://www.pcord.com/>. Access on 15 August 2016.

Mercier H \& Guerreiro Filho O (1990) Propagação sexuada de algumas bromélias nativas da mata atlántica: Efeito da luz e da temperatura na germinação. Hoehnea 17: 19-26.

Oliveira Bueno R (2012) Fatores que influenciam interações entre beija-flores e plantas em Mata Atlântica: disponibilidade de recursos e ajustes morfológicos. Doctoral Thesis. Universidade Federal do Paraná, Paraná. 107p.

Oliveira FMC, Souza AM; Corrêa BBR, Maeda TM \& Melo-de-Pinna GF (2016) Anatomía floral de Aechmea distichantha Lem. e Canistropsis billbergioides (Schult. \& Schult.f) Leme (Bromeliaceae). Hoehnea 43: 183-193.

Paggi GM, Palma-Silva C, Silveira LCT, KaltchukSantos E, Bodanese-Zanettini MH \& Bered F (2007) Fertility of Vriesea gigantea Gaud. (Bromeliaceae) in southern Brazil. American Journal of Botany 94: 683-689.

Ramírez Morillo IM, Chi May F, Carnevali G \& May Pat F (2009) It takes two to tango: self incompatibility in the bromeliad Tillandsia streptophylla (Bromeliaceae) in Mexico. Revista de Biología Tropical 57: 761-770.

Rocca MA, \& Sazima M (2013) Quantity versus quality: identifying the most effective pollinators of the hummingbird-pollinated Vriesea rodigasiana (Bromeliaceae). Plant Systematics and Evolution 299: 97-105.

Rosa AEM \& Monteiro R (2012) Bromeliaceae na apa Santuário Ecológico da Pedra Branca, Caldas, Minas Gerais. Boletim de Botânica da Universidade de São Paulo 30: 5-21.

Sazima I, Buzato S \& Sazima M (1996) An assemblage of hummingbird-pollinated flowers in a montane forest in southeastern Brazil. Botanica Acta 109: 149-160.

Sazima M \& Sazima I (1999) The perching bird Coereba flaveola as a co-pollinator of bromeliad flowers in southeastern Brazil. Canadian Journal of Zoology 77: 47-51.

Schmid S, Schmid VS, Zillikens A, Harter-Marques B \& Steiner J (2011a) Bimodal pollination system of the bromeliad Aechmea nudicaulis involving hummingbirds and bees. Plant Biology 13: 41-50.

Schmid S, Kamke R, Zillikens A \& Steiner J (2011b) Flower visitors of Aechmea nudicaulis (Bromeliaceae): species richness, visitation frequency, and interactions in different habitats of southern Brazil. Studies on Neotropical Fauna and Environment 46: 101-120.

Schmid S, Schmid VS, Zillikens A \& Steiner J (2011c) Diversity of flower visitors and their role for pollination in the ornithophilous bromeliad Vriesea friburgensis in two different habitats in southern Brazil. Ecotropica 17: 91-102.

Scrok GJ \& Varassin IG (2011) Reproductive biology and pollination of Aechmea distichantha Lem. (Bromeliaceae). Acta Botanica Brasilica 25: 571-576.

Silvertown J \& Lovett Doust J (1993) Introduction to plant population biology. Blackwell, Oxford. 210p.

Smith LB \& Downs RJ (1979) Bromeliaceae, subfamily Bromelioideae. Flora Neotropica Monograph 14: 1493-2142.

Taura HM \& Laroca S (2001) A associação de abelhas silvestres de um biótopo urbano de Curitiba (Brasil), com comparações espaço-temporais: Abundância relativa, fenologia, diversidade e explotação de recursos (Hymenoptera, Apoidea). Acta Biológica Paranaense 30: 35-137. 
Vizentin-Bugoni J, Maruyama PK \& Sazima M (2014)

Processes entangling interactions in communities: Forbidden links are more important than abundance in a hummingbird-plant network. Proceedings of the Royal Society: Biological Sciences 281: 20132397.

Vossler FG, Fagúndez GA \& Blettler DC (2014) Variability of food stores of Tetragonisca fiebrigi
(Schwarz) (Hymenoptera: Apidae: Meliponini) from the Argentine Chaco based on pollen analysis. Sociobiology 61: 449-460.

Wolowski M, Ashman TL \& Freitas L (2014) Metaanalysis of pollen limitation reveals the relevance of pollination generalization in the Atlantic Forest of Brazil. PLOS One 9: e89498. 